\title{
Article \\ Phosphodiesterase Type-5 Inhibitor Tadalafil Modulates Steroid Hormones Signaling in a Prostate Cancer Cell Line
}

\author{
Viviana M. Bimonte ${ }^{1,2,3}$, Francesco Marampon ${ }^{4}$, Ambra Antonioni ${ }^{2}$, Simona Fittipaldi ${ }^{5} \mathbb{D}$, Elisabetta Ferretti ${ }^{2} \mathbb{D}$, \\ Richard G. Pestell ${ }^{6}$ (D), Mariaignazia Curreli ${ }^{2}$, Andrea Lenzi ${ }^{2}$, Giovanni Vitale ${ }^{7,8} \mathbb{D}^{\text {, }}$, Antonio Brunetti 9 (D), \\ Silvia Migliaccio ${ }^{1,+}$ iD and Antonio Aversa ${ }^{3, *,+(\mathbb{D})}$
}

check for

updates

Citation: Bimonte, V.M.; Marampon, F.; Antonioni, A.; Fittipaldi, S.; Ferretti, E.; Pestell, R.G.; Curreli, M.; Lenzi, A.; Vitale, G.; Brunetti, A.; et al. Phosphodiesterase Type-5 Inhibitor Tadalafil Modulates Steroid Hormones Signaling in a Prostate Cancer Cell Line. Int. J. Mol. Sci. 2021, 22, 754. https://doi.org/10.3390/ ijms22020754

Received: 15 December 2020 Accepted: 8 January 2021 Published: 13 January 2021

Publisher's Note: MDPI stays neutral with regard to jurisdictional clai$\mathrm{ms}$ in published maps and institutional affiliations.

Copyright: (C) 2021 by the authors. Licensee MDPI, Basel, Switzerland. This article is an open access article distributed under the terms and conditions of the Creative Commons Attribution (CC BY) license (https:// creativecommons.org/licenses/by/ $4.0 /)$.
1 Department of Movement, Human and Health Sciences, "Foro Italico" University, 00135 Rome, Italy; v.bimonte@studenti.uniroma4.it (V.M.B.); silvia.migliaccio@uniroma4.it (S.M.)

2 Department of Experimental Medicine, "Sapienza" University of Rome, 00161 Rome, Italy; ambra.anto@hotmail.it (A.A.); elisabetta.ferretti@uniroma1.it (E.F.); mariaignazia.curreli@uniroma1.it (M.C.); andrea.lenzi@uniroma1.it (A.L.)

3 Department of Experimental and Clinical Medicine, Magna Græcia University, 88100 Catanzaro, Italy

4 Department of Radiological, Oncological and Pathological Sciences, "Sapienza" University, 00161 Rome, Italy; francesco.marampon@uniroma1.it

5 Department of Biomedicine and Prevention, "Tor Vergata" University, 00133 Rome, Italy; fttsmn01@uniroma2.it

6 Pennsylvania Cancer and Regenerative Medicine Research Center, Baruch S. Blumberg Institute, Pennsylvania Biotechnology Center, Wynnewood, PA 19111, USA; richard.pestell@bblumberg.org

7 Department of Medical Biotechnologies and Translational Medicine, University of Milan, 20122 Milan, Italy; giovanni.vitale@unimi.it

8 Laboratory of Geriatric and Oncologic Neuroendocrinology Research, Istituto Auxologico Italiano, IRCCS, Cusano Milanino, 20095 Milan, Italy; g.vitale@auxologico.it

9 Department of Health Sciences, Magna Graecia University, 88100 Catanzaro, Italy; brunetti@unicz.it

* Correspondence: aversa@unicz.it

+ These authors contributed equally to this work.

Abstract: Background: The androgen receptor (AR) plays a key role in normal prostate homeostasis and in prostate cancer (PCa) development, while the role of aromatase (Cyp19a1) is still unclear. We evaluated the effects of a treatment with Tadalafil (TAD) on both these proteins. Methods: Androgen-sensitive human PCa cell line (LnCAP) was incubated with/without TAD $\left(10^{-6} \mathrm{M}\right)$ and bicalutamide $(\mathrm{BCT})\left(10^{-4} \mathrm{M}\right)$ to evaluate a potential modulation on cell proliferation, protein and mRNA expression of Cyp19a, AR and estrogen receptor- $\beta$ (ER $\beta)$, respectively. Results: TAD increased early AR nuclear translocation ( $p<0.05$, after $15 \mathrm{~min}$ of exposure), and increased AR transcriptional activity $(p<0.05)$ and protein expression $(p<0.05)$ after $24 \mathrm{~h}$. Moreover, after $24 \mathrm{~h}$ this treatment upregulated Cyp19a1 and ER $\beta$ mRNA ( $p<0.05$ and $p<0.005$ respectively) and led to an increase in protein expression of both after $48 \mathrm{~h}(p<0.05)$. Interestingly, TAD counteracted Cyp19a1 stimulation induced by BCT $(p<0.05)$ but did not alter the effect induced by BCT on the AR protein expression. Conclusion: We demonstrate for the first time that TAD can significantly modulate AR expression and activity, Cyp19a1 and ER $\beta$ expression in PCa cells, suggesting a specific effect of these proteins. In addition, TAD potentiates the antiproliferative activity of BCT, opening a new clinical scenario in the treatment of PCa.

Keywords: tadalafil; prostate cancer; androgen resistance; aromatase; bicalutamide

\section{Introduction}

Prostate cancer (PCa) is the leading cause of male cancer death in western countries with an increasing incidence in developing countries [1]. Testosterone (T) or dihydrotestosterone (DHT) stimulate PCa cell growth by binding the androgen receptor (AR) [2]. Upon binding to the AR, the androgen/AR complex translocates to the nucleus where it dimerizes and binds to specific androgen responsive elements (AREs) within target gene promoters, 
leading to modulation of gene transcription [3]. Due to the importance of androgenic signal transduction, the androgen deprivation therapy (ADT) is widely used in clinical practices as adjuvant or neoadjuvant therapy, either alone or in combination with surgery and/or radiotherapy to block or slow down prostate cancer growth $[4,5]$. Nevertheless, $\mathrm{ADT}$ is invariably followed by the recurrence of castration-resistant prostate cancer (CRPC) with a disease relapse time within 12-18 months [6,7]. These events occur even earlier by repressing AR expression with androgen deprivation [8] and are facilitated by ADT [9]. Further, this event can evolve later by the inappropriate restoration of the AR signaling axis and the increased intracrine steroidogenesis [10]. Thus, in order to counteract and/or delay the onset of the CRPC phenotype, it may be important to find new therapeutic strategies able to support/restore AR expression at the earliest stages of disease.

Cyclic adenosine monophosphate (cAMP) and cyclic guanosine monophosphate (cGMP) are ubiquitous second messengers, which regulate multiple functions in virtually all eukaryotic cells. The deregulation of these factors has been involved in several pathophysiological processes and diseases, including cancer [11]. The phosphodiesterase (PDE) enzyme superfamily consists of 11 isoforms (PDE1-PDE11) that modulate the intracellular concentrations of cAMP and cGMP by catalyzing their degradation to inactive $5^{\prime}$ nucleotide monophosphates. Consequently, PDEs regulate many physiological processes whilst their altered expression, localization and function are implicated in the pathogenesis of several diseases [12,13], where these enzymes have been shown to be often over expressed and/or aberrantly activated, thus promoting the onset and progression of tumors [14]. In particular, increased expression of PDE5 has been reported in several human cancers [15-18], whereas its inhibition has been shown to induce anticancer effects [19-21]. These findings have been also observed in PCa, both in preclinical [22-26] and clinical experiences $[27,28]$. However, the molecular mechanism(s) by which PDE5 inhibition affects PCa homeostasis are unknown.

Interestingly, recent in vivo data suggest that estrogens may play a key role in prostate disease. Indeed, it has been reported that high estrogen levels can induce premalignant dysplasia and that their combination with high androgen levels may give rise to malignancy $[29,30]$. The production of estrogens from androgens is mediated by aromatase (Cyp19a1). This enzyme plays a pivotal role in cancer development in several tissues, particularly in the breast tissue, although its role and contribution in prostate carcinogenesis remains undefined $[29,30]$. Notably, PDE5 inhibition has a direct effect on the Cyp19a1 [31,32]. In vitro, in human osteoblastic cells, tadalafil (TAD), a PDE5 inhibitor (PDE5i), decreases Cyp19a1 expression and increases AR protein expression, suggesting a novel control of the steroid hormone pathway by PDE5i [32]. Moreover, TAD increases AR protein expression in $\mathrm{C} 2 \mathrm{C} 12$ murine muscle cells, accelerating myogenic differentiation [33].

The aims of the present study were to investigate the effects of TAD on the expression of AR and Cyp19a1, and its potential impact in modulating the antiproliferative activity of ADT in human PCa LnCAP cells.

\section{Results}

2.1. Tadalafil Increases AR Expression and Function without Affecting LNCaP Cell Viability and the Proliferation Rate

To evaluate the potential effects of TAD on AR expression and activity, LNCaP cells were incubated with TAD $\left(10^{-6} \mathrm{M}\right)$ for increasing time intervals $(24,48$ and $72 \mathrm{~h})$. As shown in Figure 1A, TAD significantly increased AR protein expression $(24 \mathrm{~h}, \mathrm{TAD}$ vs. CTL, $p<0.05$ ), which returned to near baseline levels after 48-72 h (Figure 1A). The following question was whether TAD increased AR protein expression through transcriptional and/or translational mechanism(s). After 6, 15 and $24 \mathrm{~h}$ of incubation with TAD, no significant differences were observed in AR mRNA levels between untreated and treated cells (Figure 1B, TAD+ vs. TAD-). Since the half-life of AR protein in LNCaP cells, cultured in the absence of androgens, is approximately $3 \mathrm{~h}$ [34], we investigated whether TAD increased AR by a process of protein stabilization. To address this point, $\mathrm{LNCaP}$ cells were treated with cycloheximide (CHX $10 \mu \mathrm{g} / \mathrm{mL}$ ), a well-known inhibitor of mRNA transla- 
tion [35], in the presence or absence of TAD $\left(10^{-6} \mathrm{M}\right)$ for $3 \mathrm{~h}$ (Figure 1C). As shown in Figure $1 \mathrm{C}$, TAD did not counteract CHX-induced AR protein downregulation (Figure 1C). Notably, since the treatment of LNCaP cells with TAD did not affect neither cell viability, nor cell proliferation rate at $24-48 \mathrm{~h}$ (Figure 1D), this is consonant with a non-transcriptional and non-translational effect of TAD on the upregulation of AR expression.

A
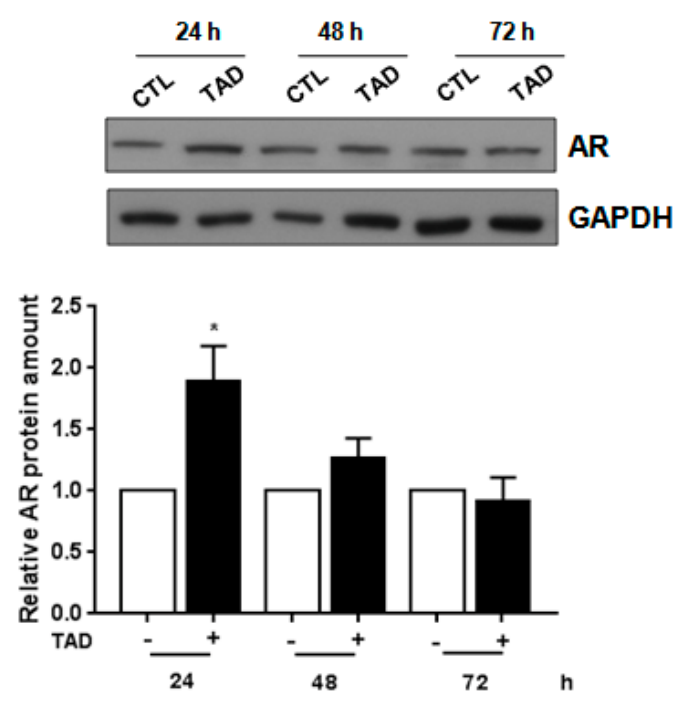

C
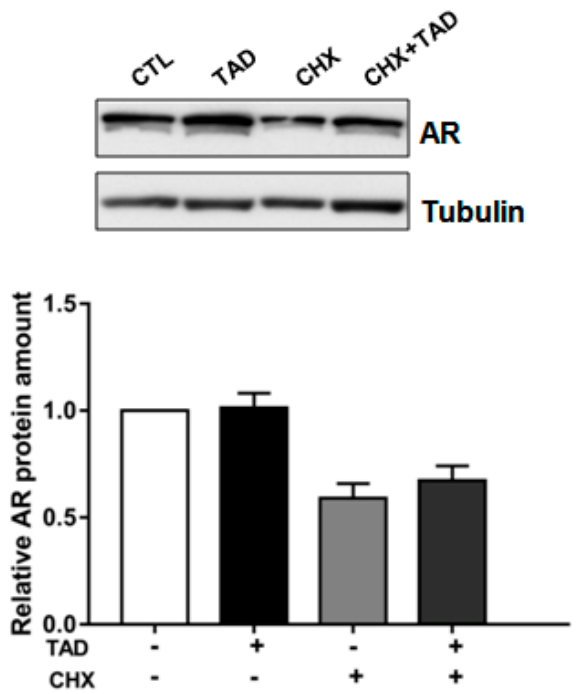

B

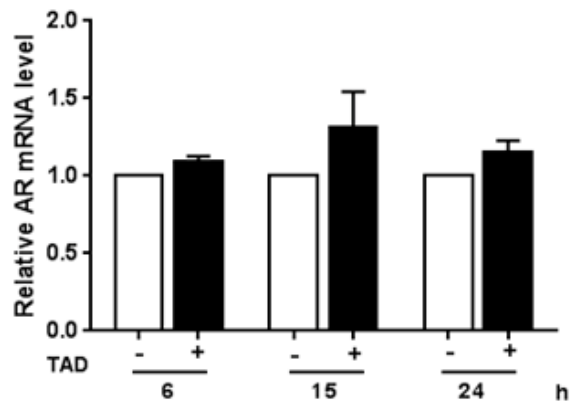

D

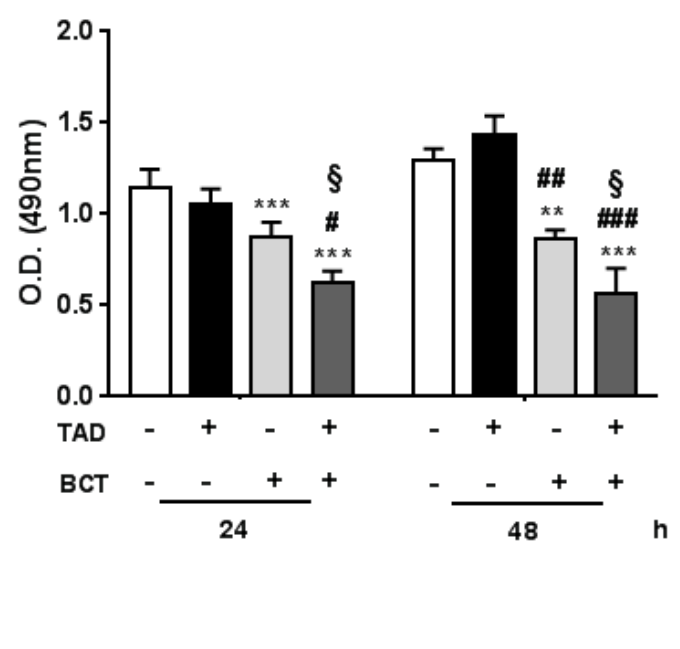

Figure 1. Effects of TAD on AR expression and LNCaP proliferation. (A) Representative Western blot analysis of AR protein expression in LNCaP cells cultured in the presence $(+)$ or in the absence (-) of TAD $\left(10^{-6} \mathrm{M}\right)$ for 24,48 and $72 \mathrm{~h}$. GAPDH was used as an internal control for protein loading. (B) Effect of TAD on AR mRNA expression in the presence (+) or in the absence (-) of TAD $\left(10^{-6} \mathrm{M}\right)$. (C) CHX effect on AR protein expression. A representative Western blot of AR protein expression is shown in LNCaP cells cultured for $3 \mathrm{~h}$ in the presence $(+)$ or in the absence $(-)$ of TAD $\left(10^{-6} \mathrm{M}\right)$, and pretreated or not with CHX $(10 \mu \mathrm{g} / \mathrm{mL})$ for $1 \mathrm{hr}$. Tubulin, control for protein loading. (D) MTS proliferation assay in LNCaP cells in cultured cells either in the presence $(+)$ or in the absence $(-)$ of TAD $\left(10^{-6} \mathrm{M}\right)$ and / or bicalutamide $\left(\mathrm{BCT}, 10^{-4} \mathrm{M}\right)$ for and 24-48 h. Results are represented as mean \pm SE $(n=3)$ of three independent experiments. ${ }^{*} p<0.05,{ }^{* *} p<0.005,{ }^{* * *} p<0.001$ vs. CTL cells, \# $p<0.05, \# \# p<0.005, \# \# \#<0.001$ vs. TAD treated cells, $\S p<0.05$ vs. BCT treated cells. 


\subsection{Tadalafil Promotes AR Nuclear Translocation and Transcriptional Activity}

LNCaP cells were used to verify whether TAD could affect AR translocation from cytoplasmic to nuclear compartment [36], and the transcriptional activity of AR. As shown in Figure 2A, 15 min of TAD $\left(10^{-6} \mathrm{M}\right)$ exposure significantly increased nuclear AR abundance (Figure 2A, TAD+ vs. TAD- $p<0.05$ ). Results were confirmed by the use of a known AR nuclear transport inhibitor, MDV3100 (MDV 10 $0^{-5} \mathrm{M}$ ) [37]. In fact, LNCaP cells, treated with MDV $\left(10^{-5} \mathrm{M}\right)+\operatorname{TAD}\left(10^{-6} \mathrm{M}\right)$ for $15 \mathrm{~min}$, showed a significant decrease of AR nuclear translocation (Figure S1, $p<0.05$ vs. CTL cells, $p<0.05$ vs. TAD treated cells, $\S$ vs. MDV treated cells).

A
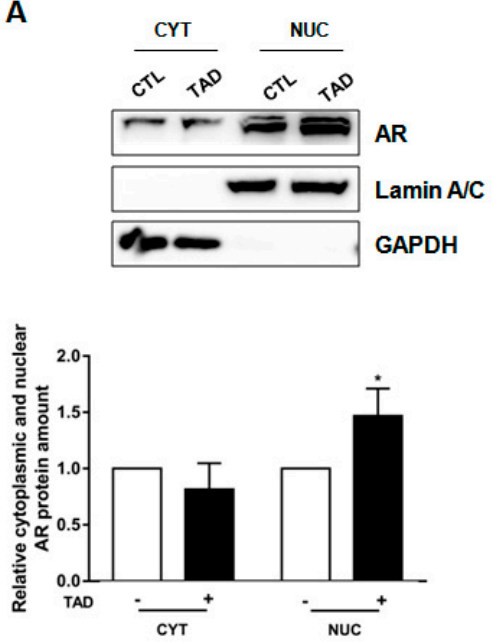

B

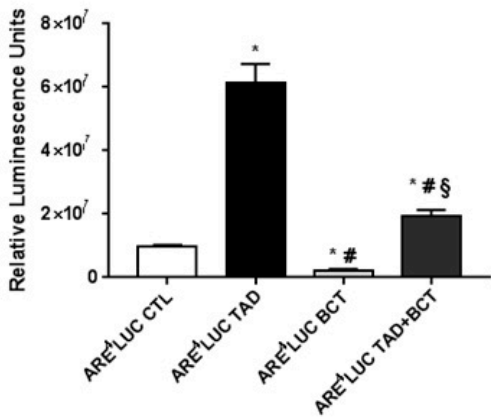

C
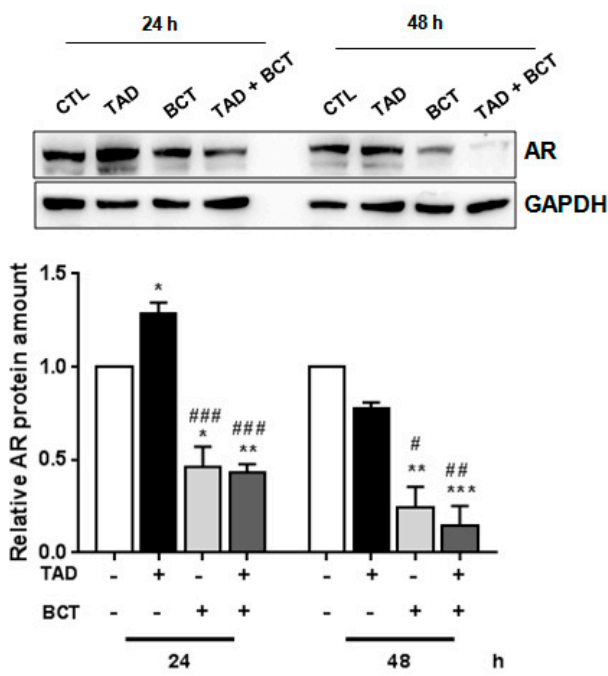

Figure 2. TAD boosts AR function and increases BCT-mediated AR downregulation. (A) Analysis of cytoplasmic (CYT) and nuclear (NUC) fractions of AR in LNCaP cells cultured in the presence (+) or in the absence $(-)$ of TAD $\left(10^{-6} \mathrm{M}\right)$ for $15 \mathrm{~min}$. GAPDH and Lamin A/C were used as loading and purity controls of each cellular fraction. (B) Effects of TAD on AR transcriptional activity. LNCaP were transfected with ARE ${ }^{4} \mathrm{LUC}$ and treated in the presence $(+)$ or in the absence $(-)$ of TAD $\left(10^{-6} \mathrm{M}\right)$ and BCT $\left(10^{-4} \mathrm{M}\right)$. Luciferase activity was measured after $24 \mathrm{~h}$. (C) Representative Western blot analysis of AR protein expression in cultured cells either in the presence $(+)$ or in the absence $(-)$ of TAD $\left(10^{-6} \mathrm{M}\right)$ and / or BCT $\left(10^{-4} \mathrm{M}\right)$ for 24-48 $\mathrm{h}$. In Western blot, GAPDH was used as a control of protein loading. Results are represented as mean $\pm \mathrm{SE}(n=3)$ of three separate experiments. ${ }^{*} p<0.05$, ${ }^{* *} p<0.005,{ }^{* * *} p<0.001$ vs. CTL cells, \# $p<0.05$, \#\# $p<0.005$, \#\# $p<0.001$ vs. TAD treated cells, $\S p<0.05$ vs. BCT treated cells. 
To test AR transcriptional activity, LNCaP cells were transiently transfected with androgen-responsive luciferase reporter vectors, in which androgen-cis elements (ARELuc) were cloned upstream the luciferase gene, and treated with TAD $\left(10^{-6} \mathrm{M}\right)$ for $24 \mathrm{~h}$, either in the presence or absence of the AR antagonist BCT $\left(10^{-4} \mathrm{M}\right)$. As shown in Figure 2B, TAD significantly increased luciferase activity (Figure $2 B$, ARE ${ }^{4} L U C$ TAD vs. ARE ${ }^{4} L U C$ $\mathrm{CTL}, p<0.05)$ and efficiently counteracted luciferase activity inhibition induced by BCT (Figure $2 \mathrm{~B}, \mathrm{ARE}^{4} \mathrm{LUC} \mathrm{TAD}+\mathrm{BCT}$ vs. $\mathrm{ARE}^{4} \mathrm{LUC} \mathrm{CTL}+\mathrm{BCT}, p<0.05$ ), strongly suggesting an AR dependent effect. By contrast, luciferase assay, performed in DU145 and PC3 cells (androgen-insensitive cells lines), showed that exposure to TAD and TAD + BCT did not affect AR activity (Figure S2A). Additionally, TAD treatment induced an increase of AR downstream target gene (Figure S2B). Indeed, long-term TAD exposure (72 h) significantly increased PSA mRNA level, (Figure S2B, $p<0.05$ vs. CTL cells). Cells were then exposed to $B C T$, which inhibited the PSA production in LNACap cells $[38,39]$. Interestingly it was observed a reduction of PSA in cells treated with either BCT alone or BCT + TAD (Supplementary Figure S2B, $p<0.05, p<0.005$ vs. CTL cells, $p<0.05, p<0.005$ vs. TAD treated cells) at any interval time evaluated (24-48-72 h) (Figure S2B, $p<0.05, p<0.005$ vs. CTL cells, $p<0.05, p<0.005$ vs. TAD treated cells). Overall, these results strongly indicate that TAD promoted nuclear translocation of the AR and, also, facilitated AR transcriptional activity.

\subsection{Tadalafil Increases In Vitro BCT-Mediated AR Downregulation and Cytostatic Effects on LNCaP Cells}

To verify whether TAD was able to improve the pharmacological efficiency of BCT in treating hormone-sensitive $\mathrm{PCa}$, cell viability was assessed in $\mathrm{LNCaP}$ cells treated with TAD $\left(10^{-6} \mathrm{M}\right)$, in the presence or absence of BCT $\left(10^{-4} \mathrm{M}\right)$. As shown in Figure $1 \mathrm{D}$, as compared to $\mathrm{BCT}$ alone, cotreatment with $\mathrm{TAD}+\mathrm{BCT}$ more efficiently reduced $\mathrm{LNCaP}$ proliferation after either 24 or $48 \mathrm{~h}$ incubation (TAD $+\mathrm{BCT}$ vs. $\mathrm{BCT}, p<0.05$ ). Although we did not detect any significant differences between $\mathrm{BCT}$ and $\mathrm{BCT}+\mathrm{TAD}$, we observed a trend of major reduction of $\mathrm{AR}$ protein expression in cells treated with TAD + BCT compared to $\mathrm{BCT}$ alone after $24 \mathrm{~h}$ (Figure $2 \mathrm{C}$, BCT vs. CTL, $p<0.05$; TAD + BCT vs. CTL, $p<0.005$ ) and $48 \mathrm{~h}$ (Figure $2 \mathrm{C}$, BCT vs. CTL, $p<0.005$; TAD + BCT vs. CTL, $p<0.001$ ). In addition, after $48 \mathrm{~h}$ the cotreatment induces a major reduction of $\mathrm{AR}$ protein expression in these treated cells as compared to cells treated only with BCT (Figure 2C, BCT vs. TAD, $p<0.05$; $\mathrm{TAD}+\mathrm{BCT}$ vs. TAD, $p<0.005)$.

\subsection{Tadalafil Modulates Aromatase and Estrogen Receptor- $\beta$ Expression}

Cyp19a1 converts androgens to estrogen [40] that in turn can impair AR expression [41]. Since we have recently shown that TAD modulates Cyp19a1 [31], we hypothesized that TAD could improve BCT-induced AR downregulation by promoting Cyp19a1 expression. Exposure of LNCaP cells to TAD $\left(10^{-6} \mathrm{M}\right)$ for $24 \mathrm{~h}$ upregulated Cyp19a1 mRNA expression (Figure 3A, TAD vs. CTL, $p<0.05$ ). Moreover, as shown in Figure 3B, both TAD and BCT alone increased Cyp19a1 protein expression after $48 \mathrm{~h}$ (TAD vs. CTL, $p<0.05$; $\mathrm{BCT}$ vs. CTL, $p<0.05)$. TAD + BCT cotreatment reduced Cyp19a1 protein expression after $48 \mathrm{~h}$ compared to either TAD (TAD + BCT vs. TAD, $p<0.05$ ) or BCT alone (TAD + BCT vs. $\mathrm{BCT}, p<0.05)$. These results indicate that the ability of TAD to improve BCT-induced AR downregulation might be mediated by Cyp19a1.

In addition, exposure of $\mathrm{LNCaP}$ cells to TAD $\left(10^{-6} \mathrm{M}\right)$ augmented estrogen receptorbeta $(E R \beta)$ levels. As shown in Figure 3C, a significant difference was observed in ER $\beta$ mRNA levels after $24 \mathrm{~h}$ of treatment between untreated and treated cells (Figure 3C, TAD+ vs. TAD- $p<0.005)$. Moreover, TAD significantly increased ER $\beta$ protein expression $(48 \mathrm{~h}$, TAD vs. CTL, $p<0.05$ ), which approximated to baseline levels after $72 \mathrm{~h}$ (Figure 3D). 


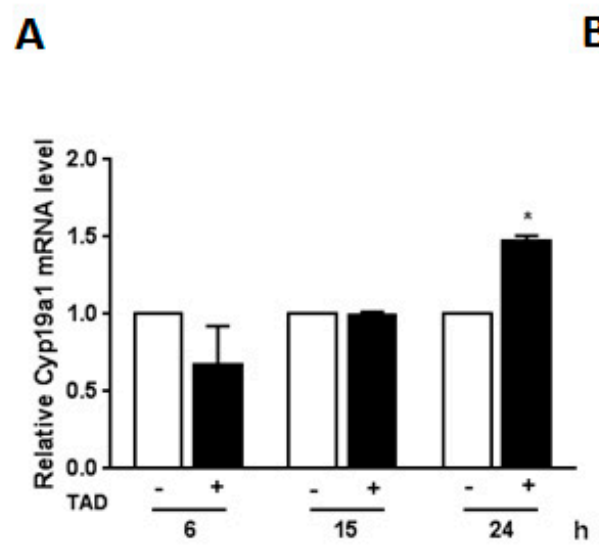

B
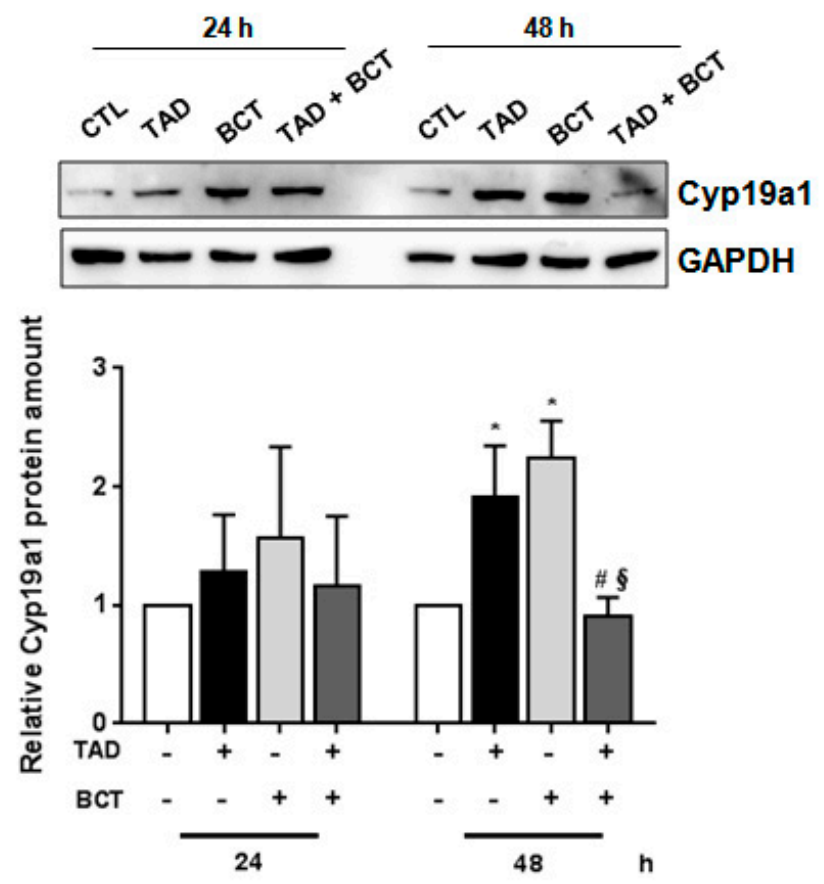

C D
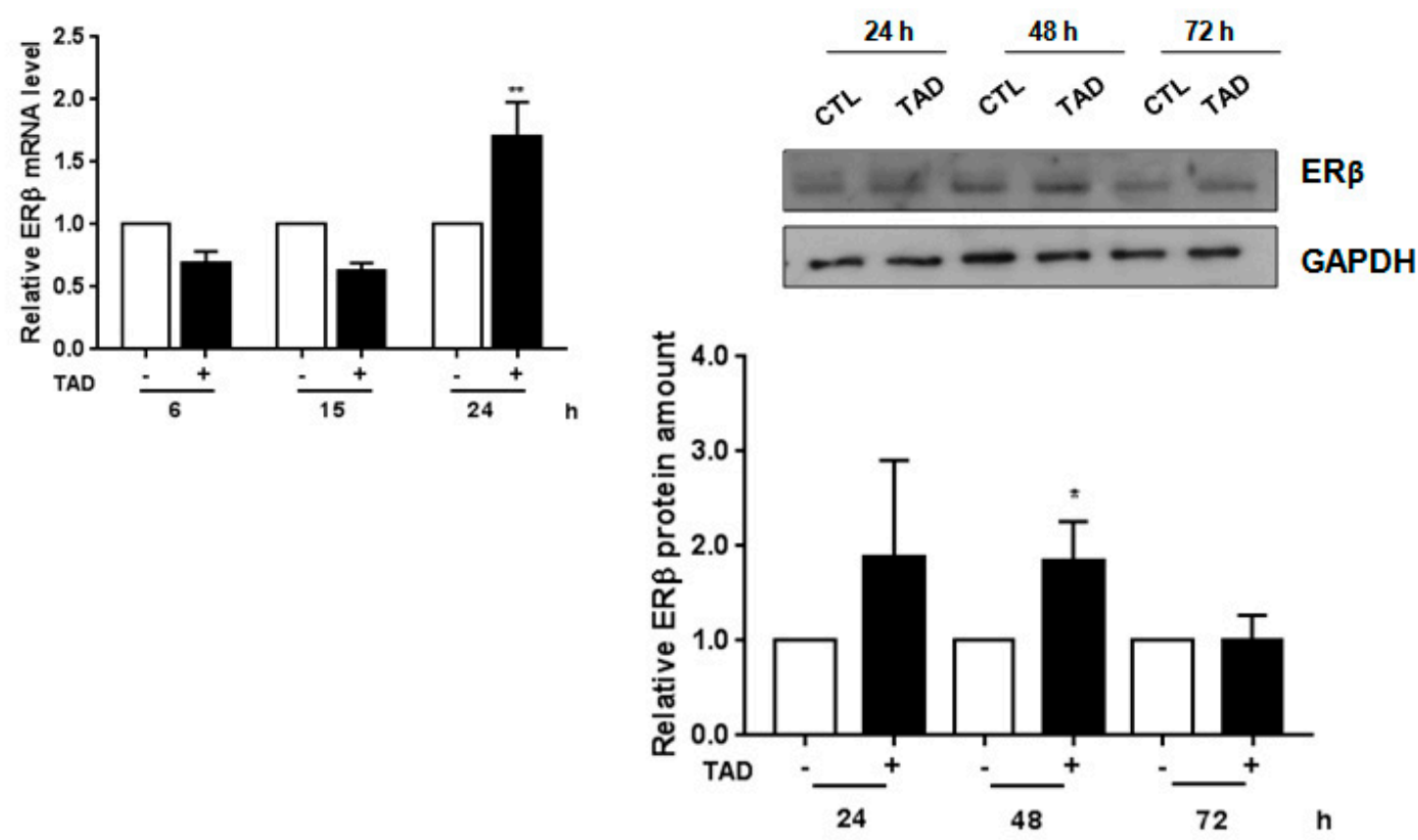

Figure 3. TAD dependent-increase of Cyp19a1 and ER $\beta$ expression and BCT-mediated Cyp19a1 downregulation. (A,C) Effect of TAD on Cyp19a1 and ER $\beta$ mRNA expression in LNCaP cells, either exposed or not to TAD $\left(10^{-6} \mathrm{M}\right)$ for 6, 15 and $24 \mathrm{~h}$. (B) A representative Western blot of Cyp19a1 protein is shown in LNCaP cells cultured in the presence $(+)$ or in the absence $(-)$ of TAD $\left(10^{-6} \mathrm{M}\right)$ and/or BCT $\left(10^{-4} \mathrm{M}\right)$ for 24 and $48 \mathrm{~h}$. (D) A representative Western blot of ER $\beta$ protein is shown in LNCaP cells cultured in the presence $(+)$ or in the absence $(-)$ of TAD $\left(10^{-6} \mathrm{M}\right)$ for 24,48 and $72 \mathrm{~h}$. GAPDH, control of protein loading. Results are shown as mean \pm SE $(n=3)$ of three separate experiments. ${ }^{*} p<0.05,{ }^{* *} p<0.005$ vs. CTL cells, $\# p<0.05$ vs. TAD treated cells, $\S p<0.05$ vs. BCT treated cells. 


\section{Discussion}

The results presented herein demonstrate for the first time that TAD can modulate AR expression in prostate cancer cells in vitro. We also show that TAD induced the stabilization and reduced the degradation of AR, which is more efficiently accumulated within the nucleus. Interestingly, this effect could lead to a potential anticancer action of TAD by enhancing the therapeutic effect of ADT.

PCa is a leading cause of death in adult males and often CRPC has a lower therapeutic response to conventional chemotherapy [42]. The expression of PDE5 and cGMP-signaling pathway in normal and cancerous prostate tissues and their possible involvement in carcinogenesis still remain controversial. TAD, sildenafil and vardenafil are employed to treat erectile dysfunction (ED) through the specific inhibition of cGMP-specific PDE5, responsible for cGMP degradation in the corpus cavernosum [43]. Currently, PDE5i are largely used as daily treatment for benign prostatic hyperplasia (BPH)-related lower urinary tract symptoms (LUTS) where they reduce spontaneous contractility of the glands, thereby reducing the muscle tone of the genitourinary tract [44] even if a specific inhibitory growth pattern on prostate tissue has not been clearly documented. Fibbi et al. reported PDE5 immunolocalization mainly in the fibromuscular stroma and vascular (endothelial and stem cells) in the rat and human prostate from BPH subjects [45]; by contrast, Ückert et al. immunolocalized PDE5 expression also at glandular and subglandular areas of human prostate cancer patients [46]. Zhang et al. reported an upregulation of PDE5 in hyperplastic human prostate thus providing a rationale for the high efficacy of PDE5 inhibitors for treating patients with LUTS/BPH with/without ED [47]. Although PDE5 inhibitors are largely used after oncological curative treatments for PCa, PDE5 immunolocalization studies in prostate adenocarcinomas have not been exhaustively reported in the literature. In order to properly localize PDE5 expression, Bisegna et al. [48] recently found PDE5 overexpression in the stromal compartment of hyperplastic prostate samples. Interestingly, their immunohistochemical study showed a $22 \%$ of PCa samples expressing PDE5 in the epithelial compartment compared to normal $(8 \%)$ or hyperplastic samples $(11 \%)$, and that such positivity was not correlated with the Gleason grading system. Recent data suggest that sildenafil and vardenafil may induce PDE5-independent apoptotic sensitization to doxorubicin (or other topoisomerase II inhibitors), thus suggesting a combinatory treatment as an important strategy for anti-CRPC development [49]. Given our previous finding of a Cyp19a1 and AR regulation by TAD in human adipocytes [31], osteoblast [32] and skeletal cell lines [33] (summarized in Figure 4A), respectively, we investigated potential actions of TAD in a different cellular model. In this PCa cell-line, the acute exposure of LNCaP to TAD did not affect cell viability and proliferation rate. TAD upregulates AR protein expression and transcriptional activity, without affecting neither metabolism nor proliferation of PCa cells. Several studies indicate that PCa is driven by the AR, a ligand-dependent transcription factor belonging to the nuclear receptor family. Multiple growth-promoting and survival pathways interact with AR signaling and are involved in PCa [50]. The rising prostatic specific antigen (PSA) levels measured in PCa patients, who become resistant to ADT, indicate that AR signaling remains an essential target for pharmacological intervention. Approaches with compounds interfering with AR signaling are currently being investigated in clinical studies [51]. Early clinical studies with agents target in programmed cell death protein 1 (PD-1) or programmed death-ligand 1 (PD-L1) are currently ongoing. As already demonstrated in other cell models [31-33], we confirm that TAD increases AR expression after $24 \mathrm{~h}$ exposure of LnCAP cell at the nuclear level; and promotes nuclear translocation of AR triggering its transcriptional activity. Additionally, cotreatment with AR-blocker BCT, produced a significant drop in LnCAP proliferation at 24 and $48 \mathrm{~h}$, thus suggesting a putative add-on action of this drug in inhibiting AR-mediated PCa cell growth (see Figure 4B). 
A

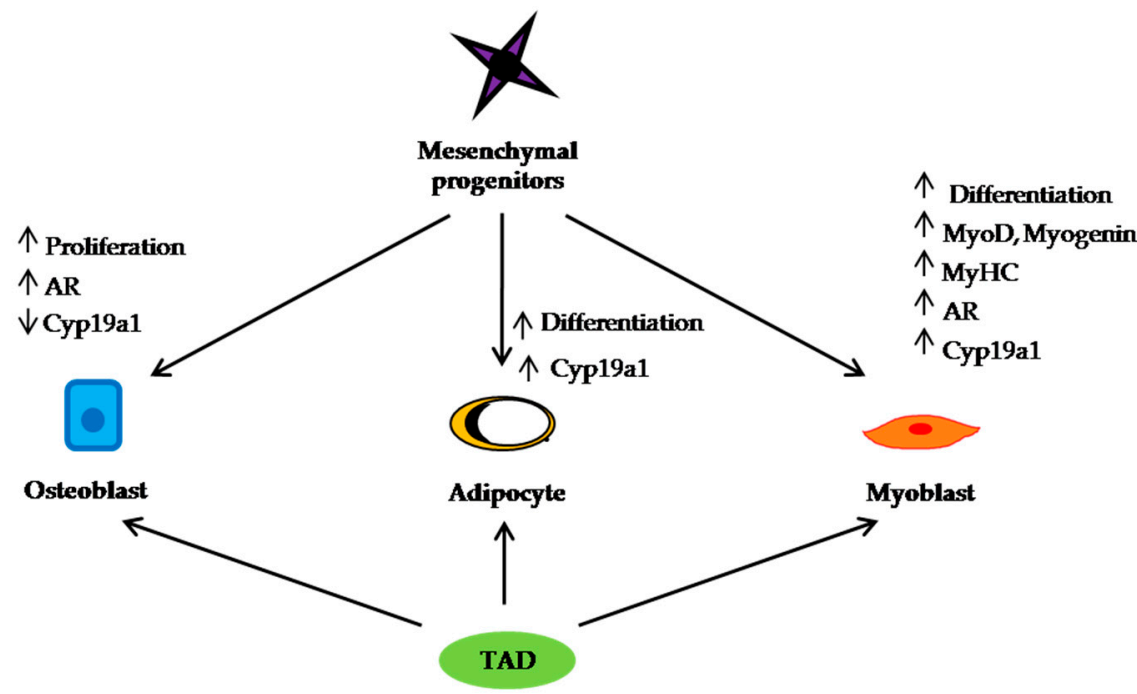

B

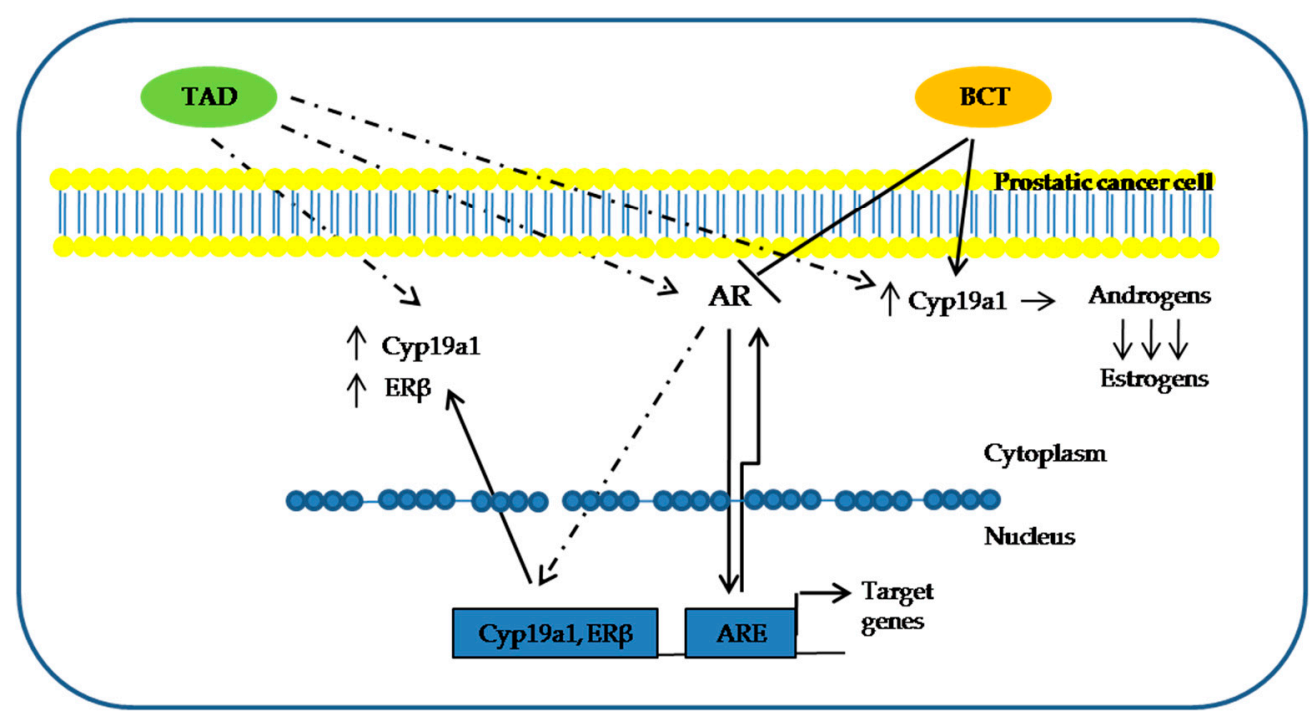

Figure 4. (A) Schematic representation of the effects of PDE5 inhibitor (PDE5i) tadalafil (TAD) on different cell lines on proliferation and differentiation. It is suggested that TAD may modulate the expression of molecules such as Cyp19a1 and the androgen receptor (AR). In particular in the osteoblastic cell, TAD leads to an increase of AR and a decrease of Cyp19a1 and it has been described an increase in cellular proliferation. In adipocyte cells TAD has a positive effect on Cyp19a1 expression. Moreover, in myoblasts, it has been reported to increase AR and Cyp19a1 proteins and of molecules involved in cell differentiation, such as MyoD, myogenin. (B) Molecular mechanism triggered by TAD in the prostate cancer cell line (dotted lines represent unexplained effects). Chronic exposure to TAD induced an increase in AR protein expression and an increase in gene and protein expression of ER $\beta$ and Cyp19a1. We hypothesize that chronic exposure to BCT may induce loss of ER $\beta$ due to induction of Cyp19a1, and cotreatment with TAD is able to block these effects.

AR is the classical target for PCa prevention and treatment, but more recently estrogens and their receptors have also been implicated in both development and tumor progression. Increasing evidence demonstrate that local estrogen signaling mechanisms are required for prostate carcinogenesis and tumor progression [52]. The effects of aromatase inhibitors (AIs) on the human prostate due to systemic estrogen depletion are becoming clinically important due to their increasing use as an adjuvant therapy in postmenopausal women with breast cancer. Cyp19a1 converts androgens into estrogens, and the role of estrogens in the pathophysiology of PCa is not well established. Bonkhoff confirmed the hypothesis according to which estrogens may play a major role in the regulation of prostate growth in men [53]. In detail, estrogen ER $\beta$ is the most prevalent ER in the human prostate, 
while the estrogen receptor alpha $(E R \alpha)$ is restricted to basal cells of the prostatic epithelium and stromal cells. In high grade prostatic intraepithelial neoplasia (HGPIN), the ER $\alpha$ might be upregulated while a partial loss of the ER $\beta$ might occur, suggesting a potential action as tumor suppressor. The ER $\beta$ is generally retained in hormone naïve and metastatic prostate cancer, but it is partially lost in castration resistant disease [54]. The progressive emergence of the ER $\alpha$ and ER $\alpha$-regulated genes (e.g., progesterone receptor, PS2, TMPRSS2-ERG fusion and NEAT1) during PCa progression and hormone refractory disease suggests that these tumors can bypass the AR by using estrogens and progestins for their growth. Indeed, in CRPC Cyp19a1 expression was significantly increased in tumor samples [55]. In PCa cell lines, the androgen receptor antagonist BCT increased Cyp19a1 expression and $\mathrm{ER} \beta$ transcriptional activity. It is well known that steroids and drugs, which bind to the intracellular receptor, might have a bell-shape curve [56-58] upon the concentration of the molecule. Thus, we believe that the TAD plus BCT combination might exert a similar effect and, at high concentration, an inhibitory effect. Moreover, it has been shown that the combinatory use of two drugs, could either exert synergistic effects, or antagonistic actions, when the combination of two drugs leads to a smaller effect than expected [59]. In addition, gene expression signature predictive of CRPC with neuroendocrine differentiation revealed an over-representation of estrogen signaling [60]. Therefore, an increase in Cyp19a1expression might be one of the mechanisms underlying CRPC development.

Our study demonstrated for the first time that chronic exposure ( $48 \mathrm{~h}$ ) to BCT produced a significant increase in Cyp19a1 mRNA in LnCAP cells, which was reverted by cotreatment with TAD. Indeed, anastrozole and selective AIs had been proposed for the treatment of men with advanced prostate cancer, but currently, results are still inconsistent [61]. Attia and Ederveen demonstrated that an increase of ER $\beta$ in prostate cells stimulates cell apoptosis and decreases cell cancer cell proliferation exerting a potential interesting pharmacological role in neoplastic lesions [62]. We herein speculate that the local increase in estrogen levels might activate ER $\beta$ intracellular pathway and that chronic exposure to BCT may induce loss of ER $\beta$ due to induction of Cyp19a1; the cotreatment with TAD is able to block these effects and thus one can hypothesize the maintenance of androgen responsiveness to antiandrogen therapy. In fact, TAD potentiated the antiproliferative activity of BCT in LNCaP cells.

The study has some limitations. We did not evaluate the potential effects of PDE5i treatment on cytokines (i.e., IFN- $\beta$ ) involved in the modulation of cell proliferation and differentiation of CRPC [63]. Furthermore, it was clear that the cotreatment of TAD and BCT strongly reverted the stimulation of Cyp19a1, but further studies aimed to clarify mechanism/s explaining enhancement of ADT by TAD are needed to evaluate the antitumor potential of these two molecules, and their role on the estrogen receptors function. Finally, we did not evaluate potential known interactions between androgen receptor blockade and downstream compounds, i.e., cAMP/PKA signaling, which may be involved in alternative pathways underlying castration-recurrent prostate cancer [64].

\section{Materials and Methods}

\subsection{Reagents}

Buffers and reagents were from Corning, and medium from PAN-Biotech. Charcoal stripped fetal bovine serum (FBS) and CHX were from Sigma Aldrich. TAD, BCT and MDV were purchased from Santa Cruz Biotechnology, dissolved in dimethylsulfoxide (Sigma Aldrich, St. Louis, MO, USA) and then added to cells at the concentrations indicated. Primary antibodies were as following: GAPDH, Millipore; tubulin, Abcam; AR, Cyp19a1, ER $\beta$ and Lamin A/C, Santa Cruz Biotechnology (Dallas, TX, USA). Trizol was purchased from Life Technologies, while the Cell Titer 96 Aqueous One Solution Cell Proliferation Assay kit was from Promega (Madison, WI, USA). 


\subsection{Cell Culture}

LNCaP cells (a human androgen sensitive PCa cell line), DU-145 and PC3 (a human androgen insensitive PCa cell line) were cultured in RPMI 1640 medium, supplemented with $2 \mathrm{mM}$ L-glutamine, $100 \mathrm{U} / \mathrm{mL}$ penicillin/streptomycin, $10 \%$ fetal bovine serum (FBS), at $37{ }^{\circ} \mathrm{C}$, and $5 \% \mathrm{CO}_{2}$ in a humidified incubator. AR-positive $\mathrm{LNCaP}$ cells and AR-negative DU-145 and PC3 were grown up to $70-80 \%$ confluence, starved overnight in serum-free medium, treated with TAD $\left(10^{-6} \mathrm{M}\right)$ or BCT $\left(10^{-4} \mathrm{M}\right)$ (or a combination of both), resuspended in medium $\mathrm{w} / \mathrm{o}$ phenol red, supplemented with $10 \%$ charcoal stripped FBS (CS-FBS) and collected after short- (15 min) or long-term $(24,48$ and $72 \mathrm{~h})$ drug exposure. For the cotreatment with TAD and BCT, cells were first pretreated for $1 \mathrm{~h}$ with BCT $\left(10^{-4} \mathrm{M}\right)$ and then cotreated with TAD $\left(10^{-6} \mathrm{M}\right)$. In regards of the cotreatment with TAD and MDV, cells were first pretreated for $2 \mathrm{~h}$ with MDV $\left(10^{-5} \mathrm{M}\right)$ and then cotreated with TAD $10^{-6} \mathrm{M}$ for $15 \mathrm{~min}$. After overnight starvation in serum-free medium, cells were pretreated for $1 \mathrm{hr}$ with $\mathrm{CHX}$, and then cotreated with TAD $\left(10^{-6} \mathrm{M}\right)$ for $3 \mathrm{~h}$ in medium w/o phenol red supplemented with $10 \%$ CS-FBS.

\subsection{Cell Proliferation Assay}

LNCaP cell viability was determined by the Cell Titer 96 Aqueous One Solution Cell Proliferation Assay kit, based on cell-mediated (3-(4,5-dimethylthiazol-2-yl)-5-(3carboxymethoxyphenyl)-2-(4-sulfophenyl)-2H-tetrazolium (MTS) reduction to formazan, following the manufacturer's protocol. Cells were plated at a density of 5000 cells/well in a 96-well culture plate, and cell viability was evaluated upon treatment with TAD $\left(10^{-6} \mathrm{M}\right)$ and BCT $\left(10^{-4} \mathrm{M}\right)$ for $24-48 \mathrm{~h}$. The absorbance was measured at $490 \mathrm{~nm}$ using a plate reader (680 Microplate Reader; Bio-Rad, Hercules, CA, USA), and expressed as the optical density value (OD). Three independent experiments were performed, each in triplicate.

\subsection{RNA Isolation and Quantitative Real-Time PCR}

For RNA extraction, cells were washed twice with PBS 1X and lysed with Trizol according to the manufacturer's instructions. The purity and integrity of total RNA was monitored by electrophoretic analysis through a denaturing agarose gel. Ultraviolet spectrophotometry (Eppendorf, Hamburg, DE) was used for RNA yield evaluation. Total RNA $(1 \mu \mathrm{g})$ was treated with DNAse I Amplification Grade (Invitrogen, Life\&Technologies, Carlsbad, CA, USA) and reverse-transcribed using the SuperScriptTM III (Invitrogen, Life\&Technologies, Carlsbad, CA, USA). Quantitative real-time PCR was performed in Abi Prism 7500 light cycler (Applied Biosystem, Waltham, MA, USA), using power SYBR green PCR master mix (Applied Biosystem, Waltham, MA, USA) as indicated by the manufacturers. All primers were optimized for amplification checking the generation of a single amplicon in a melting curve assay and the efficiency in a standard curve amplification ( $>98 \%$ for each couple of primers).

Each analysis was performed in triplicate. Relative expression levels were calculated using the comparative cycle threshold $(\Delta \Delta \mathrm{Ct})$ method, using cyclophilin $\mathrm{A}$ as an internal control. The sequences of the utilized primers were as follows:

- $\quad$ AR (NM_000044), FW: TAC CAG CTC ACC AAG CTC CT; REW: GAT GGG CTT GAC TTT CCC AG.

- $\quad$ Cyp19a1 (NM_000103), FW: ACT ACA ACC GGG TAT ATG GAGAA; REW: TCG AGA GCT GTA ATG ATT GTGC.

- $\quad$ ERß (NM_001214902), FW: AGC ACG GCT CCA TAT ACA TACC; REW: TGG ACC ACT AAA GGA GAA AGGT

- Cyclophilin A (NM_021130), FW: GTC AAC CCC ACC GTG TTC TT; REW: AAA GTT TTC TGC TGT TTT TGGAAT C.

- $\quad$ PSA (NM_001030047), FW: GAGGAGTTCTTGACCCCAAAG; REW: CGCACACACGTCATTGGAAATA.

Each sample was always analyzed in duplicate in all the experiments performed. 


\subsection{Protein Extraction and Western Blot Analysis}

After each treatment, cells were washed with phosphate-buffered saline (PBS) and lysed in fresh ice-cold RIPA buffer ( $150 \mathrm{mM} \mathrm{NaCl}, 50 \mathrm{mM}$ Tris-HCl, pH 7.5, $500 \mu \mathrm{M}$ EDTA, $100 \mu \mathrm{M}$ EGTA, $1.0 \%$ Triton X-100 and 1\% sodium deoxycholate) supplemented with a cocktail of protease and phosphatase inhibitors (Sigma Aldrich, St. Louis, MO, USA). Lysates were precleared by centrifugation and the resultant supernatant (total proteins) was collected and stored at $-80{ }^{\circ} \mathrm{C}$ until use. The NE-PER nuclear and cytoplasmic extraction kit (Thermo Fisher Scientific, Waltham, MA, USA) was used to extract nuclear and cytoplasmic fraction of cell proteins.

The protein amount was measured using the Micro BCA Protein assay kit (Thermo Scientific, Waltham, MA, USA) and analyzed by Western blot (WB) analysis. An equal amount of protein extract $(20 \mu \mathrm{g})$ was separated in SDS-PAGE (10-14\%) and transferred to nitrocellulose membrane (GE Healthcare, Chicago, IL, USA). Membranes were saturated by soaking them at RT for $1 \mathrm{~h}$ with $5 \%(w / v)$ non-fat dry milk (Cell Signalling Technology, Danvers, MA, USA), in $20 \mathrm{mM}$ Tris- $\mathrm{HCl}, 150 \mathrm{mM} \mathrm{NaCl}$ and $0.05 \%$ Tween 20 . Then, they were incubated with specific antibodies overnight at $4{ }^{\circ} \mathrm{C}$, washed three times with T-TBS $\mathrm{pH} 7.5$, and subsequently incubated for $60 \mathrm{~min}$ at room temperature with HRP-labeled secondary antibody (Jackson Laboratories, Bar Harbor, ME, USA; diluition 1:10,000) in 5\% non-fat dry milk, to detect the immunoreactive protein bands, which were visualized by enhanced chemiluminescence (GE Healthcare, Chicago, IL, USA). The bands were acquired on the ImageQuant LAS 4000 (GE Healthcare, Chicago, IL, USA) and quantified by ImageQuant TL Image analysis software (GE Healthcare, Chicago, IL, USA), using GAPDH, Lamin A/C and tubulin for normalization.

\subsection{Luciferase Assay}

Transfections were performed using the Lipofectamine 2000 reagent (Invitrogen), following the manufacturer's protocol. The androgen-responsive synthetic reporter construct, ARE ${ }^{4}$ LUC, was previously described $[65,66]$. Human rhabdomyosarcoma cell lines (RD) were used as a positive control [67]. Luciferase activity assay was performed following the manufacturer's protocol (Promega).

\subsection{Statistical Analysis}

Statistical analysis was performed by using an unpaired Student's $t$-test followed by a Mann Whitney post-hoc test (GraphPad Prism, San Diego, CA, USA). Data are presented as mean \pm standard error (SE) of at least three independent experiments. $p$ values of $<0.05$ were considered significant.

\section{Conclusions}

This study reported for the first time a novel action of TAD in a model of PCa cell line with respect to same actions previously described in other cell models in vitro [31-33]. The data herein presented suggest that TAD might lead to an increased response to antiandrogen compounds by increasing AR protein expression and activity in PCa cells in vitro. TAD treatment is widely used for the treatment of ED in patients unaware of bearing PCa. Whether these translational protective effects may apply to slow down the clinical progression of PCa to CRPC remains to be elucidated.

Supplementary Materials: Supplementary materials can be found at https://www.mdpi.com/1422 $-0067 / 22 / 2 / 754 / s 1$.

Author Contributions: Writing—original draft, writing—review and editing, V.M.B., F.M., A.A. (Antonio Aversa), S.M., E.F., G.V., A.B., A.A. (Antonio Aversa); Formal analysis, V.M.B., A.A. (Antonio Aversa), F.M., R.G.P., A.A. (Ambra Antonioni), M.C., S.F.; Methodology, V.M.B., S.F., A.A. (Antonio Aversa); Resources, G.V., A.L., A.A. (Antonio Aversa), S.M.; visualization, G.V., A.B.; supervision, funding acquisition, project administration, E.F., A.L., A.A. (Antonio Aversa), S.M. All authors have read and agreed to the published version of the manuscript. 
Funding: This study was funded by MIUR grant number 2015XCR88M_008 to A.A. (Antonio Aversa) and by PON01_00829 to A.L. V.M.B. was supported by grant number 85-2017-15308 Lazio Innova Regione Lazio to E.F. and by MIUR grant number2017HBHA98 to S.M.

Institutional Review Board Statement: Not applicable.

Informed Consent Statement: Not Applicable.

Data Availability Statement: The data presented in the study are available in the Supplementary data.

Conflicts of Interest: The authors declare no conflict of interest.

\section{Abbreviations}

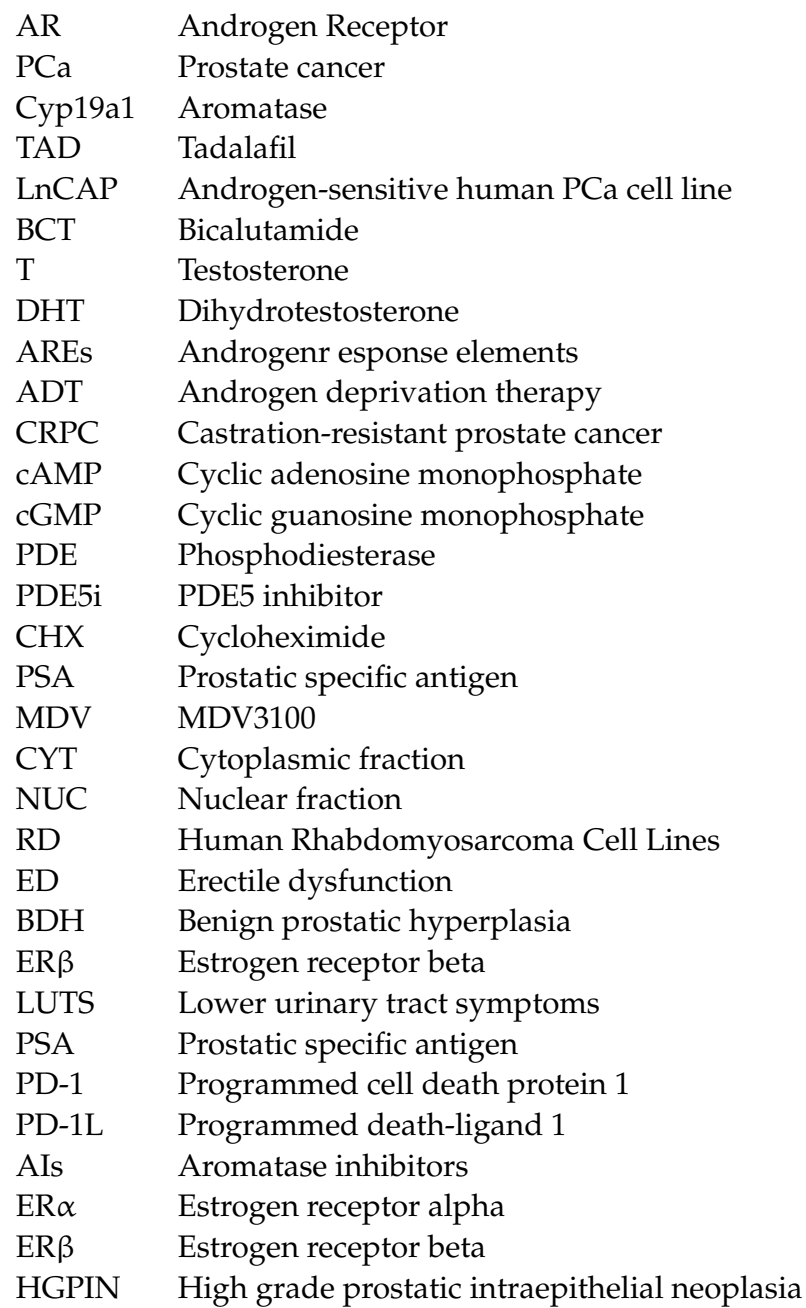

\section{References}

1. Jemal, A.; Bray, F.; Center, M.M.; Ferlay, J.; Ward, E.; Forman, D. Global cancerstatistics. CA Cancer J. Clin. 2011, 61, 69-90. [CrossRef] [PubMed]

2. Dai, C.; Heemers, H.; Sharifi, N. Androgen Signaling in Prostate Cancer. Cold Spring Harb. Perspect. Med. 2017, 7, a030452. [CrossRef] [PubMed]

3. Eder, I.E.; Culig, Z.; Putz, T.; Nessler-Menardi, C.; Bartsch, G.; Klocker, H. Molecular biology of the androgen receptor: From molecular understanding to the clinic. Eur. Urol. 2001, 40, 241-251. [CrossRef] [PubMed]

4. Crawford, E.D.; Heidenreich, A.; Lawrentschuk, N.; Tombal, B.; Pompeo, A.C.L.; Mendoza-Valdes, A.; Miller, K.; Debruyne, F.M.J.; Klotz, L. Androgen targeted therapy in men with prostate cancer: Evolving practice and future considerations. Prostate Cancer Prostatic Dis. 2019, 22, 24-38. [CrossRef]

5. Wadosky, K.M.; Koochekpour, S. Molecular mechanisms underlying resistance to androgen deprivation therapy in prostate cancer. Oncotarget 2016, 7, 64447-64470. [CrossRef] 
6. Sharifi, N.; Gulley, J.L.; Dahut, W.L. Androgen deprivation therapy for prostate cancer. JAMA 2005, 294, 238-244. [CrossRef]

7. Di Nunno, V.; Mollica, V.; Santoni, M.; Gatto, L.; Schiavina, R.; Fiorentino, M.; Brunocilla, E.; Ardizzoni, A.; Massari, F. New Hormonal Agents in Patients with Nonmetastatic Castration-Resistant Prostate Cancer: Meta-Analysis of Efficacy and Safety Outcomes. Clin. Genitourin. Cancer 2019, 17, e871-e877. [CrossRef]

8. Albany, C.; Alva, A.S.; Aparicio, A.M.; Singal, R.; Yellapragada, S.; Sonpavde, G.; Hahn, N.M. Epigenetics in prostate cancer. Prostate Cancer 2011, 2011, 580318. [CrossRef]

9. Liu, T.; Wu, L.Y.; Fulton, M.D.; Johnson, J.M.; Berkman, C.E. Prolonged androgen deprivation leads to downregulation of androgen receptor and prostate-specific membrane antigen in prostate cancer cells. Int. J. Oncol. 2012, 41, 2087-2092. [CrossRef]

10. Scher, H.I.; Sawyers, C.L. Biology of progressive, castration-resistant prostate cancer: Directed therapies targeting the androgenreceptor signaling axis. J. Clin. Oncol. 2005, 23, 8253-8261. [CrossRef]

11. Ahmad, F.; Murata, T.; Shimizu, K.; Degerman, E.; Maurice, D.; Manganiello, V. Cyclic nucleotide phosphodiesterases: Important signaling modulators and therapeutic targets. Oral Dis. 2015, 21, e25-e50. [CrossRef] [PubMed]

12. Maurice, D.H.; Ke, H.; Ahmad, F.; Wang, Y.; Chung, J.; Manganiello, V.C. Advances in targeting cyclic nucleotide phosphodiesterases. Nat. Rev. Drug Discov. 2014, 13, 290-314. [CrossRef] [PubMed]

13. Francis, S.H.; Busch, J.L.; Corbin, J.D.; Sibley, D. cGMP-dependent protein kinases and cGMP phophodiesterases in nitric oxide and cGMP action. Pharmacol. Rev. 2010, 62, 525-563. [CrossRef]

14. Levy, I.; Horvath, A.; Azevedo, M.; de Alexandre, R.B.; Stratakis, C.A. Phosphodiesterase function and endocrine cells: Links to human disease and roles in tumor development and treatment. Curr. Opin. Pharmacol. 2011, 11, 689-697. [CrossRef]

15. Catalano, S.; Campana, A.; Giordano, C.; Gyorffy, B.; Tarallo, R.; Rinaldi, A.; Bruno, G.; Ferraro, A.; Romeo, F.; Lanzino, M.; et al. Expression and function of phosphodiesterase type 5 in human breast cancer cell lines and tissues: Implications for targeted therapy. Clin. Cancer Res. 2016, 22, 2271-2282. [CrossRef]

16. Piazza, G.A.; Thompson, W.J.; Pamukcu, R.; Alila, H.W.; Whitehead, C.M.; Liu, L.; Fetter, J.R.; Gresh, W.E.J.; Klein-Szanto, A.J.; Farnell, D.R.; et al. Exisulind, a novel proapoptotic drug, inhibits rat urinary bladder tumorigenesis. Cancer Res. 2011, 61, 3961-3968.

17. Pusztai, L.; Zhen, J.H.; Arun, B.; Rivera, E.; Whitehead, C.; Thompson, W.J.; Nealy, K.M.; Gibbs, A.; Symmans, W.F.; Esteva, F.J.; et al. Phase 1 and 2 study of exisulind in combination with capecitabine in patients with metastatic breast cancer. J. Clin. Oncol. 2003, 21, 3454-3461. [CrossRef]

18. Whitehead, C.M.; Earle, K.A.; Fetter, J.; Xu, S.; Hartman, T.; Chan, D.C.; Zhao, T.L.; Piazza, G.; Klein-Szanto, A.J.; Pamukcu, R.; et al. Exisulind-induced apoptosis in a non-small cell lung cancer orthotopic lung tumor model augments docetaxel treatment and contributes to increased survival. Mol. Cancer Ther. 2003, 2, 479-488.

19. Barone, I.; Giordano, C.; Bonofiglio, D.; Andò, S.; Catalano, S. Phosphodiesterase Type 5 and Cancers: Progress and Challenges. Oncotarget 2017, 8, 99179-99202. [CrossRef]

20. Savai, R.; Pullamsetti, S.S.; Banat, G.A.; Weissmann, N.; Ghofrani, H.A.; Grimminger, F.; Schermuly, R.T. Targeting cancer with phosphodiesterase inhibitors. Expert Opin. Investig. Drugs 2010, 19, 117-131. [CrossRef]

21. Barone, I.; Giordano, C.; Bonofiglio, D.; Catalano, S.; Andò, S. Phosphodiesterase type 5 as a candidate therapeutic target in cancers. Curr. Pathobiol. Rep. 2015, 3, 193-201. [CrossRef]

22. Goluboff, E.T.; Shabsigh, A.; Saidi, J.A.; Weinstein, I.B.; Mitra, N.; Heitjan, D.; Piazza, G.A.; Pamukcu, R.; Buttyan, R.; Olsson, C.A Exisulind (sulindac sulfone) suppresses growth of human prostate cancer in a nude mouse xenograft model by increasing apoptosis. Urology 1999, 53, 440-445. [CrossRef]

23. Baetek, J.; Mistrik, M.; Bartkova, J. Long-distance inflammatory and genotoxic impact of cancer in vivo. Proc. Natl. Acad. Sci. USA 2010, 107, 17861-17862.

24. Das, A.; Durrant, D.; Mitchell, C.; Dent, P.; Batra, S.K.; Kukreja, R.C. Sildenafil (Viagra) sensitizes prostate cancer cells to doxorubicin-mediated apoptosis through CD95. Oncotarget 2016, 7, 4399-4413. [CrossRef] [PubMed]

25. Liu, N.; Mei, L.; Fan, X.; Tang, C.; Ji, X.; Hu, X.; Shi, W.; Qian, Y.; Hussain, W.J.; Wang, C.; et al. Phosphodiesterase 5/protein kinase G signal governs stemness of prostate cancer stem cells through Hippo pathway. Cancer Lett. 2016, 378, 38-50. [CrossRef]

26. Zenzmaier, C.; Sampson, N.; Pernkopf, D.; Plas, E.; Untergasser, G.; Berger, P. Attenuated proliferation and trans-differentiation of prostatic stromal cells indicate suitability of phosphodiesterase type 5 inhibitors for prevention and treatment of benign prostatic hyperplasia. Endocrinology 2010, 151, 3975-3984. [CrossRef]

27. Chavez, A.H.; ScottCoffield, K.; Hasan Rajab, M.; Jo, C. Incidence rate of prostate cancer in men treated for erectile dysfunction with phosphodiesterase type 5 inhibitors: Retrospective analysis. Asian J. Androl. 2013, 15, 246-248. [CrossRef]

28. Zelefsky, M.J.; Fuks, M.J.; Hunt, M.; Lee, H.J.; Lombardi, D.; Ling, C.C.; Reuter, V.E.; Venkatraman, E.S.; Leibel, S.A. High dose radiation delivered by intensity modulated conformal radiotherapy improves the outcome of localized prostate cancer. J. Urol. 2001, 166, 876-881. [CrossRef]

29. Morais-Santos, M.; Werneck-Gomes, H.; Campolina-Silva, G.H.; Santos, L.C.; Mahecha, G.A.B.; Hess, R.A.; Oliveira, C.A. Basal Cells Show Increased Expression of Aromatase and Estrogen Receptor $\alpha$ in Prostate Epithelial Lesions of Male Aging Rats. Endocrinology 2018, 159, 723-732. [CrossRef]

30. Ellem, S.J.; Risbridger, G.P. Aromatase and prostate cancer. Minerva Endocrinol. 2006, 31, 1-12. 
31. Aversa, A.; Caprio, M.; Antelmi, A.; Armani, A.; Brama, M.; Greco, E.A.; Francomano, D.; Calanchini, M.; Spera, G.; Di Luigi, L.; et al. Exposure to phosphodiesterase type 5 inhibitors stimulates aromatase expression in human adipocytes in vitro. J. Sex. Med. 2011, 8, 696-704. [CrossRef] [PubMed]

32. Aversa, A.; Fittipaldi, S.; Bimonte, V.M.; Wannenes, F.; Papa, V.; Francomano, D.; Greco, E.A.; Lenzi, A.; Migliaccio, S. Tadalafil modulates aromatase activity and androgen receptor expression in a human osteoblastic cell in vitro model. J. Endocrinol. Investig. 2016, 39, 199-205. [CrossRef]

33. Aversa, A.; Fittipaldi, S.; Francomano, D.; Bimonte, V.M.; Greco, E.A.; Crescioli, C.; Di Luigi, L.; Lenzi, A.; Migliaccio, S. Tadalafil improves lean mass and endothelial function in normal men with mild ED/LUTS: In vivo and in vitro characterization. Endocrine 2017, 56, 639-648. [CrossRef] [PubMed]

34. Gregory, C.W.; Johnson, R.T.; Mohler, J.L.; French, F.S.; Wilson, E.M. Androgen receptor stabilization in recurrent prostate cancer is associated with hypersensitivity to low androgen. Cancer Res. 2001, 61, 2892-2898. [PubMed]

35. Cai, C.; He, H.H.; Chen, S.; Coleman, I.; Wang, H.; Fang, Z.; Chen, S.; Nelson, P.S.; Liu, X.S.; Brown, M.; et al. Androgen Receptor Gene Expression in Prostate Cancer Is Directly Suppressed by the Androgen Receptor Through Recruitment ofLysine-Specific Demethylase 1. Cancer Cell 2011, 20, 457-471. [CrossRef] [PubMed]

36. Tan, M.H.E.; Li, J.; Xu, H.E.; Melcher, K.; Yong, E.L. Androgen Receptor: Structure, Role in Prostate Cancer and Drug Discovery. Acta Pharmacol. Sin. 2015, 36, 3-23. [CrossRef]

37. Kuruma, H.; Matsumoto, H.; Shiota, M.; Bishop, J.; Lamoureux, F.; Thomas, C.; Briere, D.; Los, G.; Gleave, M.; Fanjul, A.; et al. A novel antiandrogen, Compound 30, suppresses castration-resistant and MDV3100-resistant prostate cancer growth in vitro and in vivo. Mol. Cancer Ther. 2013, 12, 567-576. [CrossRef]

38. Masiello, D.; Cheng, S.; Bubley, G.J.; Lu, M.L.; Balk, S.P. Bicalutamide functions as an androgen receptor antagonist by assembly of a transcriptionally inactive receptor. J. Biol. Chem. 2002, 277, 26321-26326. [CrossRef]

39. Tran, C.; Ouk, S.; Clegg, N.J.; Chen, Y.; Watson, P.A.; Arora, V.; Wongvipat, J.; Smith-Jones, P.M.; Yoo, D.; Kwon, A.; et al. Development of a second-generation antiandrogen for treatment of advanced prostate cancer. Science 2009, 324, 787-790. [CrossRef]

40. Stocco, C. Tissue Physiology and Pathology of Aromatase. Steroids 2012, 77, 27-35. [CrossRef]

41. Cardone, A.; Angelini, F.; Varriale, B. Autoregulation of estrogen and androgen receptor mRNAs and downregulation of androgen receptor mRNA by estrogen in primary cultures of lizard testis cells. Gen. Comp. Endocrinol. 1998, 110, 227-236. [CrossRef] [PubMed]

42. Culp, M.B.; Soerjomataram, I.; Efstathiou, J.A.; Bray, F.; Jemal, A. Recent global patterns in prostate cancer incidence and mortality rates. Eur. Urol. 2020, 77, 38. [CrossRef] [PubMed]

43. Peak, T.C.; Yafi, F.A.; Sangkum, P.; Hellstrom, W.J. Emerging drugs for the treatment of erectile dysfunction. Exp. Opin. Emerg. Drugs 2015, 20, 263. [CrossRef] [PubMed]

44. Kügler, R.; Mietens, A.; Seidensticker, M.; Tasch, S.; Wagenlehner, F.M.; Kaschtanow, A.; Tjahjono, Y.; Tomczyk, C.U.; Beyer, D.; Risbridger, G.P.; et al. Novel imaging of the prostate reveals spontaneous gland contraction and excretory duct quiescence together with different drug effects. FASEB J. 2018, 32, 1130. [CrossRef]

45. Fibbi, B.; Morelli, A.; Vignozzi, L.; Filippi, S.; Chavalmane, A.; De Vita, G.; Marini, M.; Gacci, M.; Vannelli, G.B.; Sandner, P.; et al. Characterization of phosphodiesterase type 5 expression and functional activity in the human male lower urinary tract. J. Sex. Med. 2010, 7, 59. [CrossRef]

46. Ückert, S.; Küthe, A.; Jonas, U.D.O.; Stief, C.G. Characterization and functional relevance of cyclic nucleotide phosphodiesterase isoenzymes of the human prostate. J. Urol. 2001, 166, 2484. [CrossRef]

47. Zhang, W.; Zang, N.; Jiang, Y.; Chen, P.; Wang, X.; Zhang, X. Upregulation of phosphodiesterase type 5 in the hyperplastic prostate. Sci. Rep. 2015, 5, 17888. [CrossRef]

48. Bisegna, C.; Gravina, G.L.; Pierconti, F.; Martini, M.; Larocca, L.; Rossi, P.; Grimaldi, P.; Di Stasi, S.; Jannini, E.A. Regulation of PDE5 expression in normal prostate, benign prostatic hyperplasia, and adenocarcinoma. Andrology 2020, 8, 427. [CrossRef]

49. Chang, J.F.; Hsu, J.L.; Sheng, Y.H.; Leu, W.J.; Yu, C.C.; Chan, S.H.; Chan, M.L.; Hsu, L.C.; Liu, S.P.; Guh, J.H. Phosphodiesterase Type 5 (PDE5) Inhibitors sensitize topoisomerase II inhibitors in killing prostate cancer through PDE5-independent impairment of HR and NHEJ DNA repair systems. Front. Oncol. 2019, 8, 681. [CrossRef]

50. Nevedomskaya, E.; Baumgart, S.J.; Haendler, B. Recent Advances in Prostate Cancer Treatment and Drug Discovery. Int. J. Mol. Sci. 2018, 19, 1359. [CrossRef]

51. Sumanasuriya, S.; De Bono, J. Treatment of Advanced Prostate Cancer-A Review of Current Therapies and Future Promise. Cold Spring Harb. Perspect. Med. 2018, 8, a030635. [CrossRef]

52. Bonkhoff, H.; Berges, R. The evolving role of estrogens and their receptors in the development and progression of prostate cancer. Eur. Urol. 2009, 55, 533. [CrossRef]

53. Bonkhoff, H. Estrogen receptor signaling in prostate cancer: Implications for carcinogenesis and tumor progression. Prostate 2018, 78, 2. [CrossRef]

54. Park, K.; Dalton, J.T.; Narayanan, R.; Barbieri, C.E.; Hancock, M.L.; Bostwick, D.G.; Steiner, M.S.; Rubin, M.A. TMPRSS2:ERG gene fusion predicts subsequent detection of prostate cancer in patients with high-grade prostatic intraepithelial neoplasia. J. Clin. Oncol. 2014, 32, 206. [CrossRef] [PubMed] 
55. Liang, Z.; Cao, J.; Tian, L.; Shen, Y.; Yang, X.; Lin, Q.; Zhang, R.; Liu, H.; Du, X.; Shi, J.; et al. Aromatase-induced Endogenous Estrogen Promotes Tumour Metastasis Through Estrogen Receptor- $\alpha /$ Matrix Metalloproteinase 12 Axis Activation in CastrationResistant Prostate Cancer. Cancer Lett. 2019, 467, 72-84. [CrossRef]

56. Migliaccio, S.; Newbold, R.R.; Teti, A.; Jefferson, W.J.; Toverud, S.U.; Taranta, A.; Bullock, B.C.; Suggs, C.A.; Spera, G.; Korach, K.S. Transient estrogen exposure of female mice during early development permanently affects osteoclastogenesis in adulthood. Bone 2000, 27, 47-52. [CrossRef]

57. Krapf, J.M.; Simon, J.A. A sex-specific dose-response curve for testosterone: Could excessive testosterone limit sexual interaction in women? Menopause 2017, 24, 462-470. [CrossRef] [PubMed]

58. Schilling, T.M.; Kölsch, M.; Larra, M.F.; Zech, C.M.; Blumenthal, T.D.; Frings, C.; Schächinger, H. For whom the bell (curve) tolls: Cortisol rapidly affects memory retrieval by an inverted U-shaped dose-response relationship. Psychoneuroendocrinology 2013, 38, 1565-1572. [CrossRef] [PubMed]

59. Greco, W.R.; Bravo, G.; Parsons, J.C. The search for synergy: A critical review from a response surface perspective. Pharmacol. Rev. 1995, 47, 331-385.

60. Ostano, P.; Mello-Grand, M.; Sesia, D.; Gregnanin, I.; Peraldo-Neia, C.; Guana, F.; Jachetti, E.; Farsetti, A.; Chiorino, G. Gene Expression Signature Predictive of Neuroendocrine Transformation in Prostate Adenocarcinoma. Int. J. Mol. Sci. 2020, 21, 1078. [CrossRef]

61. Smith, M.R.; Kaufman, D.; George, D.; Oh, W.K.; Kazanis, M.; Manola, J.; Kantoff, P.W. Selective aromatase inhibition for patients with androgen-independent prostate carcinoma. Cancer 2002, 95, 1864. [CrossRef] [PubMed]

62. Attia, D.M.A.; Ederveen, A.G.H. Opposing roles of ER $\alpha$ and ER $\beta$ in the genesis and progression of adenocarcinoma in the rat ventral prostate. Prostate 2012, 72, 1022. [CrossRef] [PubMed]

63. Dicitore, A.; Grassi, E.S.; Borghi, M.O.; Gelmini, G.; Cantone, M.C.; Gaudenzi, G.; Persani, L.; Caraglia, M.; Vitale, G. Antitumor activity of interferon- $\beta 1$ a in hormone refractory prostate cancer with neuroendocrine differentiation. J. Endocrinol. Investig. 2017, 40, 761. [CrossRef] [PubMed]

64. Sadar, M.D. The role of cAMP in regulating the androgen receptor. In Androgen Actions in Prostate Cancer; Tindall, D., Mohler, J., Eds.; Springer Science + Business Media LLC: Heidelberg, Germany, 2009; 465p.

65. Fu, M.; Wang, C.; Reutens, A.T.; Wang, J.; Angeletti, R.H.; Siconolfi-Baez, L.; Ogryzko, V.; Avantaggiati, M.L.; Pestell, R.G. p300 and p300/cAMP-response element-binding protein-associated factor acetylate the androgen receptor at sites governing hormone-dependent transactivation. J. Biol. Chem. 2000, 275, 20853-20860. [CrossRef] [PubMed]

66. Fu, M.; Wang, C.; Wang, J.; Zhang, X.; Sakamaki, T.; Yeung, Y.G.; Chang, C.; Hopp, T.; Fuqua, S.A.; Jaffray, E.; et al. Androgen receptor acetylation governs trans activation and MEKK1-induced apoptosis without affecting in vitro sumoylation and transrepression function. Mol. Cell. Biol. 2002, 22, 3373-3388. [CrossRef] [PubMed]

67. Giannattasio, S.; Megiorni, F.; Di Nisio, V.; Del Fattore, A.; Fontanella, R.; Camero, S.; Antinozzi, C.; Festuccia, C.; Gravina, G.L.; Cecconi, S.; et al. Testosterone-mediated activation of androgenic signalling sustains in vitro the transformed and radioresistant phenotype of rhabdomyosarcoma cell lines. J. Endocrinol. Investig. 2019, 42, 183-197. [CrossRef] 